\title{
Evaluation of arterial stiffness in patients with psoriasis vulgaris
}

\section{Psoriazis vulgaris hastalarında arterivel sertliğin değerlendirilmesi}

\section{Emine Çölgeçen, ๑ Hüseyin Ede*, ๑ Mustafa Fatih Erkoç**, ๑ Yurdanur Akyüz**, ๑ Ali Riza Erbay*}

Yozgat Bozok University Faculty of Medicine, Department of Dermatology; *Department of Cardiology; **Department of Radiology, Yozgat,

\footnotetext{
Abstract

Background and Design: This study aimed to compare neutrophil-lymphocyte ratio (NLR), carotid intima-media thickness (CIMT), epicardial fat tissue (EFT), and arterial stiffness values of psoriatic patients with healthy subjects and to determine the relation of these parameters with the severity of psoriasis.

Materials and Methods: This study included 102 patients with psoriasis and 102 control subjects matched according to age and gender. CIMT, echocardiographic EFT, arterial stiffness [aortic stiffness index (ASI) and aortic distensibility], anthropometric measurements, psoriasis area and severity index (PASI) score, and metabolic parameters were measured in all patients.

Results: The mean NLR in the psoriasis group were significantly higher than in the healthy group $(2.3 \pm 0.74 \mathrm{vs} 1.49 \pm 0.36 ; p<0.01)$. Additionally, CIMT $(0.95 \pm 0.25$ vs $0.57 \pm 0.13 \mathrm{~mm} ; p<0.01)$, EFT $(0.77 \pm 0.23$ vs $0.42 \pm 0.12 \mathrm{~cm} ; p<0.01)$, and ASI $(3.21 \pm 0.37$ vs $2.55 \pm 0.28 ; p<0.01)$ were significantly increased in patients with psoriasis than control subjects. Also, NLR was shown to be higher among psoriatic patients with PASI of $\geq 10$. NLR was not correlated with CIMT, EFT, and ASI in psoriatic patients. Among psoriatic patients, ASI and EFT were positively correlated with age, body mass index, waist circumference, systolic blood pressure, diastolic blood pressure, triglyceride, and uric acid, whereas CIMT was positively correlated with age and waist circumference ( $p<0.05$ for all comparisons).

Conclusion: We found that psoriatic patients had higher atherosclerotic burden than healthy subjects and NLR had a stronger relation with the severity of psoriasis.

Keywords: Arterial stiffness, carotid intima-media thickness, epicardial fat tissue, neutrophil-lymphocyte ratio, psoriasis vulgaris

Öz

Amaç: Psoriatik hastaların nötrofil-lenfosit oranı (NLO), karotis intima media kalınlığı (KiMK), epikardiyal yağ dokusu (EYD) kalınlığı ve arteryel sertlik değerlerini sağıklı denekler ile karşılaştırmayı ve bu parametrelerin psoriazis şiddeti ile ilişkisini araştırmayı amaçladık.

Gereç ve Yöntem: Çalıșmaya psoriazisli 102 hasta, yaş ve cinsiyet olarak eșleștirilmiş 102 kontrol dahil edildi. Tüm hastalarda KiMK, ekokardiyografik EYD, arteryel sertlik [aortik sertlik indeksi (ASi) ve aortik esneyebililik], antropometrik ölçümler, psoriazis alan ve şiddet indeksi (PAŞi) skoru ve metabolik parametreler ölçüldü.

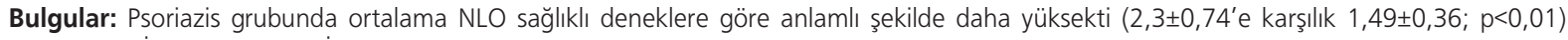

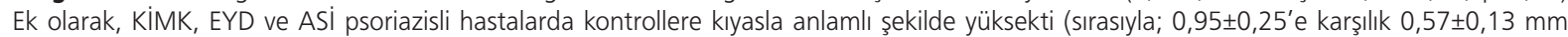

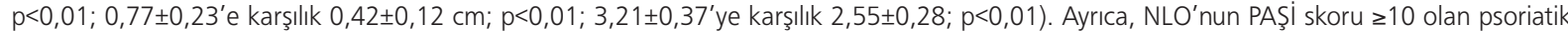
hastalarda daha yüksek olduğu gösterildi. Psoriatik hastalarda NLO değeri KiMK, EYD ve ASi ile korelasyon göstermiyordu. Psoriazisli hastalarda ASi ve EYD yaş, vücut kitle indeksi, bel çevresi, sistolik kan basıncı, diyastolik kan basıncı, trigliserit ve ürik asit düzeyleri ile pozitif korelasyona sahipken, KiMK yaş ve bel çevresi ile negatif korelasyona sahipti (tüm karşılaştırmalar için $p<0,05$ ).

Sonuç: Psoriatik hastaların sağlıklı deneklere kıyasla daha fazla aterosklerotik yüke sahip olduğunu ve NLO'nun psoriazis şiddeti ile güçlü bir ilişkisi olduğunu bulduk.

Anahtar Kelimeler: Arteryel sertleșme, karotis intima media kalınlı̆ı, epikardiyal yağ dokusu, nötrofil-lenfosit oranı, psoriazis vulgaris

This study was presented as a poster at the $25^{\text {nd }}$ National Dermatology Congress.

Address for Correspondence/Yazışma Adresi: Emine Çölgeçen MD, Yozgat Bozok University Faculty of Medicine, Deparment of Dermatology, Yozgat, Turkey Phone: +90 3542127010 E-mail: drecolgecen@hotmail.com Received/Geliș Tarihi: 06.12.2019 Accepted/Kabul Tarihi: 22.06.2020 ORCID: orcid.org/0000-0001-9651-6068 


\section{Introduction}

Psoriasis is a common chronic inflammatory skin disease that affects $1.5 \%-3 \%$ of the general population ${ }^{1}$. It is thought to arise from the interaction of immunologic, genetic, and environmental factors ${ }^{2}$. Several recent studies have linked psoriasis to an increased risk of cardiovascular diseases ${ }^{3-5}$. Altered expression of pro-inflammatory cytokines, which are critical mediators of systemic inflammation, has also been reported in patients with psoriasis.

Lymphopenia and neutrophilia have recently been identified as independent predictors of mortality in cardiovascular diseases ${ }^{6,7}$. The neutrophil-lymphocyte ratio (NLR) is an essential marker of inflammation in both cardiovascular and non-cardiovascular diseases ${ }^{8-11}$.

Plaque frequency and carotid intima-media thickness (CIMT) are established markers of subclinical atherosclerosis and clinically predictive markers of stroke and myocardial infarction risk ${ }^{12}$. Significant CIMT elevation has been observed in psoriatic patients in previous studies compared with control subjects ${ }^{3,5,13}$.

The visceral adipose tissue surrounding the heart between the visceral epicardium and myocardial epicardium is known as the epicardial fat tissue (EFT). This may contribute to the development of coronary artery disease (CAD) by promoting increased production of leptin and other adipokines, tumor necrosis factor-alpha (TNF- $\alpha$ ), visfatin, omentin, and resistin through the vasovasorum and into the lumen of the coronary artery $^{14,15}$. Studies have reported a close relation between EFT and the presence and severity of $C A D^{16,17}$. A thickness of $\geq 0.7 \mathrm{~cm}$ is regarded as abnormal $\mathrm{EFT}^{16}$. This may therefore represent an indicator of the presence of CAD and should also encourage further evaluation in asymptomatic subjects ${ }^{16,17}$

Arterial stiffness and elastic characteristics are quantified as aortic distensibility (AD) and aortic stiffness index (ASI). An increase in ASI and decrease in $A D$ indicate reduced aortic elasticity ${ }^{18}$. Non-invasive echocardiography is commonly used to evaluate $A D, A S I$, and EFT ${ }^{16,18,19}$. Our review of the literature revealed that no previous studies have investigated the atherosclerotic burden of psoriatic patients with multiple parameters reflecting subclinical atherosclerosis, such as EFT, $\mathrm{CIMT}, \mathrm{AD}$, and $\mathrm{ASI}$, and their relations with one another. There is also a lack of knowledge in the literature concerning the relation between these parameters and the severity of psoriasis. The purpose of this study was therefore to compare psoriatic patients with otherwise healthy subjects in terms of NLR and subclinical atherosclerosis markers including CIMT, EFT, ASI, and AD and to investigate the role of these parameters in differentiating the severity of psoriasis.

\section{Materials and Methods}

The Yozgat Bozok University Faculty of Medicine Local Ethics Committee reviewed and granted approval for all clinical protocols (approval number: 05.05.2014/67). Signed informed consent documents were provided by all study participants. The recommendations of the Declaration of Helsinki on human subject research were used to guide and inform all pertinent ethical considerations.

\section{Study population}

This prospective cross-sectional study was performed over a 6-month period. The study population consisted of 102 patients with psoriasis vulgaris ( 56 women and 46 men, mean age: $40.9 \pm 8.6$ years and mean duration of disease $12.2 \pm 10.4$ years) referred for treatment to the Bozok University Faculty of Medicine, Department of Dermatology, Turkey, and 102 age- and gender-matched control subjects (56 women and 46 men, mean age: $43.1 \pm 6.7$ years). Physical and histopathological findings were used in the diagnosis of psoriasis vulgaris. The following clinical characteristics were evaluated for each participant: Sex, age, tobacco use, disease duration, waist circumference, and body mass index (BMI). BMI was defined as weight $(\mathrm{kg})$ divided by height $(\mathrm{m})$ squared. The following blood biochemical parameters were evaluated for all participants: C-reactive protein (CRP), fasting blood glucose, NLR (calculated as a ratio of neutrophils to lymphocytes obtained from a single complete blood count), thyroid-stimulating hormone (TSH), lowdensity lipoprotein (LDL) cholesterol, high-density lipoprotein (HDL) cholesterol, total cholesterol, and triglyceride levels.

All subjects were free of any known cardiovascular or ischemic organ diseases. Patients with CAD history (detected by previous coronary angiography, scintigraphy, or coronary tomographic angiography), acute coronary syndrome, peripheral arterial disease, [hypertension (HT); diastolic blood pressure (DBP) $>90 \mathrm{mmHg}$ and/or systolic BP (SBP) $>140 \mathrm{mmHg}],<50 \%$ left ventricular ejection fraction (LVEF), moderate or severe valvular regurgitation and/or stenosis, heavy tobacco use ( $\geq 25$ cigarettes per day), [diabetes mellitus (DM); venous plasma glucose $>110 \mathrm{mg} / \mathrm{dL}$ after overnight fasting], renal insufficiency (serum creatinine levels exceeding $1.3 \mathrm{mg} / \mathrm{dL}$ ), regular alcoholic beverage consumption (two or more drinks per day), cancer, chronic obstructive pulmonary disease, active bacterial infection or upper respiratory tract viral infection, and fever history $\left(>38.3^{\circ} \mathrm{C}\right)$ or upper respiratory tract symptoms within the previous 2 weeks were excluded. Patients who were pregnant and lactating and had previous echocardiography and electrocardiograph (ECG) findings indicating myocardial infarction or coronary artery bypass grafting were also excluded. Patients with chest pain or dyspnea who underwent prompt ECG, echocardiography, and cardiac stress tests promptly and those with suspected or confirmed diagnosis of CAD based on the test results were also excluded.

\section{EFT measurement}

Echocardiography was conducted by a cardiologist blinded to the study groups using ultrasound device (Presound alpha 7, IPF 1701 Model, 2009; Hitachi Aloka Medical Ltd., Tokyo, Japan) with a 2.5$\mathrm{MHz}$ transducer. Standard two-dimensional measurements (left atrial diameter and LVEF) were obtained as advised by the American Society of Echocardiography ${ }^{19}$.

EFT was defined as the relatively echo-free cavity between the right ventricle and visceral pericardium. Maximum EFT thickness at end-systole was employed during analyses. The position of the midventricular free wall inside the right ventricle at the mid-point of the ultrasound beam, perpendicular to the aortic annulus, was employed as an anatomic reference ${ }^{20}$. The mean of three cardiac cycles was calculated. EFT thickness measurements were recorded by a cardiologist blinded to the study. Abnormal EFT was defined as a thickness of $\geq 0.7 \mathrm{~cm}^{16}$. A total of 20 patients were randomly selected for echocardiographic examination, and EFT thickness measurements were repeated after 1 week to assess intraobserver variability. The reproducibility of the measurement was highly significant for that variability (intraclass correlation coefficient: $0.918, p<0.001)$. 


\section{Assessment of CIMT and arterial stiffness}

BP was measured from both arms by a clinician blinded to the study groups, with the subject in a seated position. BP was measured twice over a 5 min interval. DBP and SBP were recorded using a sphygmomanometer. The mean value of the four BP measurements was recorded. Pulse pressure was defined as the difference between SBP and DBP.

Echocardiographic examination was conducted by a cardiologist blinded to the study groups using an ultrasound machine (Presound alpha 7, IPF 1701 Model) with a $2.5 \mathrm{MHz}$ transducer. Standard two-dimensional measurements were performed as recommended by the American Society of Echocardiography ${ }^{19}$. Following the echocardiographic cardiac examination at parasternal long axis M-mode images, the systolic (Asd) and diastolic (Add) aortic diameters of the ascending aorta from the lower margin of the upper wall as far as the upper margin of the lower wall were calculated $3 \mathrm{~cm}$ distal to the aortic valve level, with diastole and systole being differentiated using simultaneous ECG recordings. ASI was calculated using the formula ASI= $\ln (\mathrm{SBP} / \mathrm{DBP}) /[($ Asd-Add)/Add], and $A D$ was measured with the formula $A D\left[1 /\left(10^{3} \times \mathrm{mmHg}\right)\right]=2 \times[($ AsdAdd)/Add]/PP18.

Carotid Doppler ultrasonography was performed using an Aloka Prosound A6 (Hitachi Aloca Medical) equipped with a $7.5 \mathrm{MHz}$ linear-array imaging probe. A single blinded radiologist performed all measurements with the patient in a supine position, with the neck extended and head faced away from the region under investigation. The transducer was located in the longitudinal plane to maximize the diameter of the lumen. The images were enhanced with magnification to yield high-resolution detail at a location $1 \mathrm{~cm}$ proximal to the carotid bifurcation. The distance between the media-adventitia and lumen-intima interfaces was used to determine the CIMT of the far wall. Measurements were taken at $1 \mathrm{~mm}$ intervals bilaterally from five contiguous sites. The mean value of all measurements from each patient was employed for statistical analyses. CIMT values exceeding 1 mm were considered abnorma ${ }^{21}$

\section{Assessment of psoriasis severity}

The psoriasis area and severity index (PASI) score was applied to evaluate the clinical severity of psoriasis ${ }^{22}$.

\section{Statistical Analysis}

SPSS software was used for all statistical analyses. Categorical variables were expressed as proportions (\%) and continuous variables as mean \pm standard deviation. The chi-square test was used to compare categorical variables. Pearson or Spearman simple correlation analyses were used to determine relations between continuous parameters, and Student's t-test, the Mann-Whitney $U$ test, and Kruskal-Wallis analysis were used for group comparisons. For multivariate analysis, potential factors detected at univariate analyses were further subjected to logistic regression analysis to identify independent predictors of psoriasis severity. Hosmer-Lemeshow goodness of fit statistics was used to assess model fit. A 5\% type 1 error level was used to infer statistical significance. The capacity of ASI, AD, and EFT to differentiate psoriatic patients was tested using receiver operating characteristic (ROC) curve analyses. A 5\% type 1 error level was used to determine statistical significance at area under the curve (AUC) analysis. Statistical significance was set at $\mathrm{p}<0.05$.

\section{Results}

The clinical characteristics of all study participants are summarized in Table 1. The two groups were similar in terms of BMI, fasting glucose, creatinine, and cholesterol levels, DBP, age, gender, and smoking history (Table 1). Mean serum CRP concentrations and NLR were significantly higher in the psoriasis group than in the healthy control group $(6.2 \pm 3.2$ vs $4.3 \pm 1.9 \mathrm{mg} / \mathrm{L}, \mathrm{p}<0.01 ; 2.3 \pm 0.74$ vs $1.49 \pm 0.36 ; p<0.01$, respectively). CIMT, EFT, and ASI were significantly higher $(0.95 \pm 0.25$ vs $0.57 \pm 0.13$ $\mathrm{mm}, \mathrm{p}<0.01 ; 0.77 \pm 0.23$ vs $0.42 \pm 0.12 \mathrm{~cm}, p<0.01 ; 3.21 \pm 0.37$ vs $2.55 \pm 0.28, p<0.01$, respectively) in patients with psoriasis compared

Table 1. Demographic, clinical, and laboratory features of both groups

\begin{tabular}{|c|c|c|c|}
\hline & $\begin{array}{l}\text { Psoriasis } \\
\text { group } \\
(n=102)\end{array}$ & $\begin{array}{l}\text { Control } \\
\text { group } \\
(n=102)\end{array}$ & p \\
\hline Age (years) & $40.9 \pm 8.6$ & $43.1 \pm 6.7$ & 0.08 \\
\hline Sex (female/male), $n$ & $56 / 46$ & $56 / 46$ & 1 \\
\hline Smoking, n (\%) & $34(33.3)$ & $33(32.4)$ & 0.8 \\
\hline $\mathrm{BMI}\left(\mathrm{kg} / \mathrm{m}^{2}\right)$ & $29.7 \pm 6.8$ & $27.5 \pm 2.4$ & 0.10 \\
\hline Waist circumference $(\mathrm{cm})$ & $99.3 \pm 13.9$ & $98.0 \pm 12.9$ & 0.50 \\
\hline $\mathrm{SBP}(\mathrm{mmHg})$ & $122.3 \pm 10.4$ & $115.5 \pm 9.7$ & $<0.01$ \\
\hline $\mathrm{DBP}(\mathrm{mmHg})$ & $75.9 \pm 5.9$ & $75.8 \pm 3.9$ & 0.72 \\
\hline LVEF (\%) & $64.2 \pm 2.3$ & $63.7 \pm 2.9$ & 0.11 \\
\hline CIMT (mm) & $0.95 \pm 0.25$ & $0.57 \pm 0.13$ & $<0.01$ \\
\hline $\mathrm{EFT}(\mathrm{mm})$ & $7.7 \pm 0.5$ & $4.2 \pm 0.3$ & $<0.01$ \\
\hline ASI & $3.21 \pm 0.37$ & $2.55 \pm 0.28$ & $<0.01$ \\
\hline$A D$ & $3.1 \pm 1.2$ & $6.5 \pm 2.5$ & $<0.01$ \\
\hline Fasting glucose (mg/dL) & $99.3 \pm 16.2$ & $99.9 \pm 12.5$ & 0.09 \\
\hline Creatinine $(\mathrm{mg} / \mathrm{dL})$ & $0.85 \pm 0.14$ & $0.87 \pm 0.14$ & 0.16 \\
\hline Uric acid (mg/dL) & $5.3 \pm 1.5$ & $4.5 \pm 0.9$ & $<0.01$ \\
\hline Total cholesterol (mg/dL) & $188 \pm 44$ & $191 \pm 36$ & 0.63 \\
\hline LDL cholesterol (mg/dL) & $116 \pm 34$ & $123 \pm 29$ & 0.15 \\
\hline HDL cholesterol (mg/dL) & $43 \pm 9$ & $42 \pm 8$ & 0.07 \\
\hline Triglyceride (mg/dL) & $153 \pm 113$ & $151 \pm 60$ & 0.08 \\
\hline CRP (mg/L) & $6.2 \pm 3.2$ & $4.3 \pm 1.9$ & $<0.01$ \\
\hline NLR & $2.3 \pm 0.74$ & $1.49 \pm 0.36$ & $<0.01$ \\
\hline PASI & $15.2 \pm 5.1$ & - & - \\
\hline Disease duration (years) & $12.2 \pm 10.4$ & - & - \\
\hline Topical steroid, n (\%) & $95(93.1)$ & - & - \\
\hline Topical calcipotriol, n (\%) & $34(33.3)$ & - & - \\
\hline Methotrexate, n (\%) & $20(19.6)$ & - & - \\
\hline Acitretin, n (\%) & $16(15.7)$ & - & - \\
\hline Ciclosporin, n (\%) & $6(5.9)$ & - & - \\
\hline Phototherapy, n (\%) & $3(2.9)$ & - & - \\
\hline \multicolumn{4}{|c|}{$\begin{array}{l}\text { Values are mean } \pm \text { standard deviation unless otherwise indicated. } \\
\text { BMI: Body mass index, SBP: Systolic blood pressure, DBP: Diastolic blood pressure, } \\
\text { LVEF: Left ventricular ejection fraction, CIMT: Carotid intima-media thickness, EFT: } \\
\text { Epicardial fat tissue, ASI: Aortic stiffness index, AD: Aortic distensibility, LDL: Low- } \\
\text { density lipoprotein, HDL: High-density lipoprotein, CRP: C-reactive protein, NLR: } \\
\text { Neutrophil-lymphocyte ratio, PASI: Psoriasis area and severity index score }\end{array}$} \\
\hline
\end{tabular}


with controls (Figure 1). NLR did not correlate with CIMT, EFT, ASI, or $A D$ in psoriatic patients.

Correlation analysis results between ASI, CIMT, and EFT and age, BMI, waist circumference, SBP, DBP, LVEF, PASI, disease duration, NLR, CRP, lipid profile, fasting blood glucose, and uric acid levels in patients with psoriasis are shown Table 2. Age was found to be well and positively correlated with ASI, CIMT, and EFT but was negatively correlated with AD. BMI and waist circumference were weakly associated with ASI and AD but moderately with EFT. PASI, disease duration, and CRP were not correlated with ASI, CIMT, or EFT among psoriatic patients (Figure 2). Interestingly, a significant relationship was observed between serum

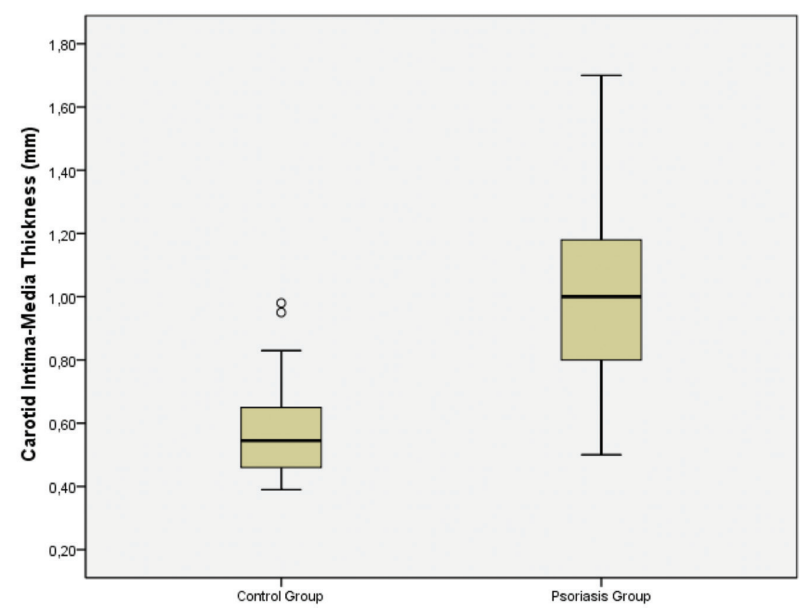

Figure 1. A. Comparison of carotid intima-media thickness between the psoriasis and control groups uric acid levels and subclinical atherosclerosis markers such as $A S I, A D$, and EFT. A similar relation was also shown for serum triglyceride levels in contrast to total cholesterol, LDL, or HDL levels.

Psoriatic subjects were categorized into two subgroups to classify the severity of the disease: One subgroup had PASI scores $<10$ and one with scores $\geq 10$. Of psoriatic patients, $78 \%$ ( $n=80$ ) had PASI scores $\geq 10$, and the remainder $(n=22)$ had PASI scores $<10$. Psoriatic subjects with PASI $\geq 10$ had significantly higher NLR values compared with psoriatic subjects with PASI $<10(2.43 \pm 0.75$ vs $1.84 \pm 0.47$, respectively, $p<0.001$, z-score: -3.621), whereas the two subgroups had similar ASI, CIMT, and

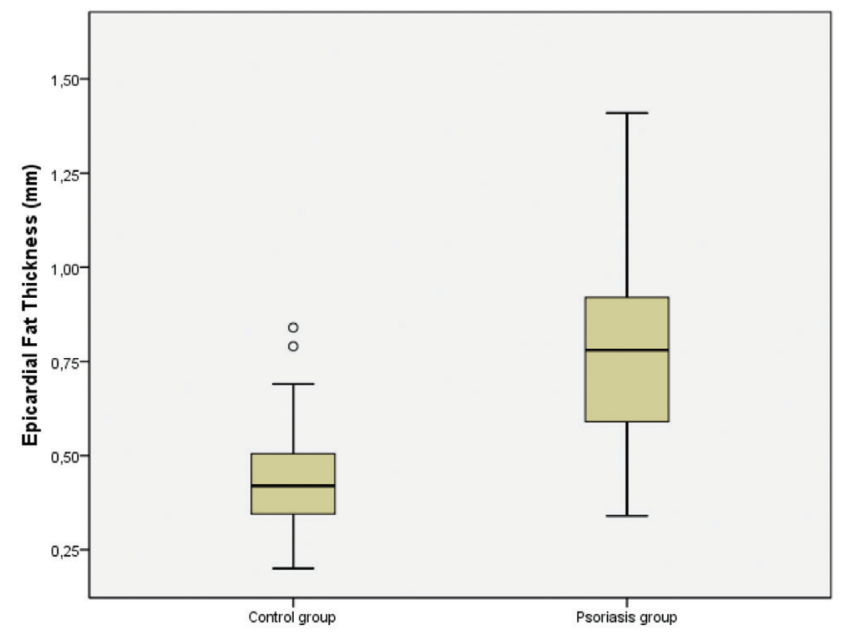

Figure 1. B. Comparison of epicardial fat thickness between the psoriasis and control groups

Table 2. The correlation of clinical and laboratory findings, aortic elasticity, CIMT, and EFT among the patients with psoriasis

\begin{tabular}{|c|c|c|c|c|c|c|c|c|}
\hline & \multicolumn{2}{|l|}{ ASI } & \multicolumn{2}{|l|}{$A D$} & \multicolumn{2}{|c|}{ CIMT (mm) } & \multicolumn{2}{|c|}{$\mathrm{EFT}(\mathrm{cm})$} \\
\hline & $r$ & $\mathbf{p}$ & $r$ & $p$ & $r$ & $p$ & $r$ & $p$ \\
\hline Age (years) & 0.280 & 0.004 & -0.318 & 0.001 & 0.453 & $<0.001$ & 0.507 & $<0.001$ \\
\hline Body mass index $\left(\mathrm{kg} / \mathrm{m}^{2}\right)$ & 0.206 & 0.038 & -0.227 & 0.022 & 0.130 & 0.193 & 0.526 & $<0.001$ \\
\hline Waist circumference $(\mathrm{cm})$ & 0.201 & 0.043 & -0.226 & 0.023 & 0.233 & 0.019 & 0.538 & $<0.001$ \\
\hline $\mathrm{SBP}(\mathrm{mmHg})$ & 0.464 & $<0.001$ & -0.625 & $<0.001$ & 0.169 & 0.089 & 0.350 & $<0.001$ \\
\hline $\mathrm{DBP}(\mathrm{mmHg})$ & 0.221 & 0.026 & -0.341 & $<0.001$ & 0.150 & 0.133 & 0.374 & $<0.001$ \\
\hline LVEF (\%) & 0.048 & 0.629 & 0.010 & 0.919 & -0.118 & 0.239 & -0.109 & 0.275 \\
\hline PASI & -0.004 & 0.972 & -0.013 & 0.894 & 0.026 & 0.792 & -0.124 & 0.215 \\
\hline Disease duration (years) & 0.048 & 0.629 & -0.056 & 0.579 & 0.087 & 0.385 & -0.112 & 0.262 \\
\hline $\operatorname{CRP}(\mathrm{mg} / \mathrm{L})$ & -0.009 & 0.927 & -0.026 & 0.793 & -0.030 & 0.763 & -0.064 & 0.520 \\
\hline NLR & 0.090 & 0.366 & -0.115 & 0.251 & 0.112 & 0.262 & -0.050 & 0.614 \\
\hline Fasting glucose (mg/dL) & -0.075 & 0.453 & 0.095 & 0.344 & 0.249 & 0.011 & 0.212 & 0.032 \\
\hline Total cholesterol (mg/dL) & 0.150 & 0.138 & -0.188 & 0.062 & 0.009 & 0.928 & 0.063 & 0.536 \\
\hline Triglyceride (mg/dL) & 0.427 & $<0.001$ & -0.495 & $<0.001$ & 0.072 & 0.479 & 0.205 & 0.042 \\
\hline HDL cholesterol (mg/dL) & -0.175 & 0.083 & -0.198 & 0.050 & -0.064 & 0.530 & -0.184 & 0.069 \\
\hline LDL cholesterol (mg/dL) & 0.137 & 0.177 & -0.156 & 0.123 & 0.036 & 0.722 & 0.092 & 0.368 \\
\hline Uric acid (mg/dL) & 0.281 & 0.004 & -0.230 & 0.020 & $<0.001$ & 0.999 & 0.348 & $<0.001$ \\
\hline
\end{tabular}


EFT values. ROC curve analyses were performed for ASI and NLR. A cut-off value of 2.82 was calculated for ASI for differentiating psoriatic patients from healthy subjects $[89 \%$ sensitivity, $82 \%$ specificity, AUC with $95 \%$ confidence interval $(\mathrm{Cl}): 0.944, \mathrm{p}<0.001$ ]. A cut-off value of 1.60 was calculated for NLR for differentiating psoriatic patients from healthy subjects (83\% sensitivity, $78 \%$ specificity, AUC with $95 \% \mathrm{Cl}$ : $0.862, \mathrm{p}<0.001)$.

Of patients, $61 \%(n=62)$ with psoriasis had abnormal EFT thicknesses, and $39 \%(n=40)$ had abnormal CIMT values. If the cut-off value of 2.82 and above was set as abnormal ASI, $89 \%$ of the psoriatic patients $(n=91)$ and $17 \%$ of the control subjects $(n=17)$ had abnormal ASI values.

Logistic regression analyses demonstrated that age, family history of cardiovascular risk factors, BMI, waist circumference, SBP, DBP, biochemistry findings, TSH, and smoking are unable to predict disease severity. Additionally, CIMT, ASI, and EFT parameters were also unable to predict disease severity. NLR was the only parameter that can predict disease severity at logistic regression analysis.

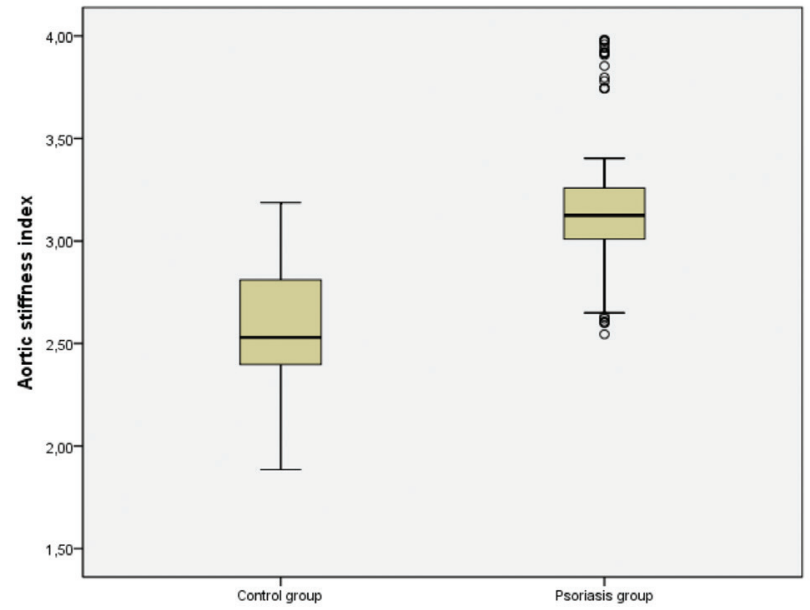

Figure 1. C. Comparison of aortic stiffnes index between the psoriasis and control groups

\section{Discussion}

Our results showed that psoriasis is associated with increased NLR, CIMT, EFT, and ASI and decreased AD compared with healthy control subjects. However, NLR exhibited no significant correlation with CIMT, $\mathrm{EFT}$, or ASI in psoriasis patients. These results are consistent with previous reports linking psoriasis with atherosclerosis-25,13,14,23. Clinical signs and symptoms vary widely among psoriasis patients. NLR seems to assist in the differentiation of psoriatic patients from healthy controls. Therefore, we propose the inclusion of NLR as a clinically informative biomarker in determining the severity, treatment, and management of patients with psoriasis.

Psoriatic patients are known to be at greater risk of developing atherosclerotic vascular disease and vascular inflammation ${ }^{24,25}$. Atherosclerosis may begin early in life ${ }^{3}$. Early diagnosis of vascular disease is of critical importance for effective intervention. The development of non-invasive diagnostic methods has greatly improved the detection and early treatment of vascular disease. The use of high-resolution ultrasonography to measure CIMT has enabled precise

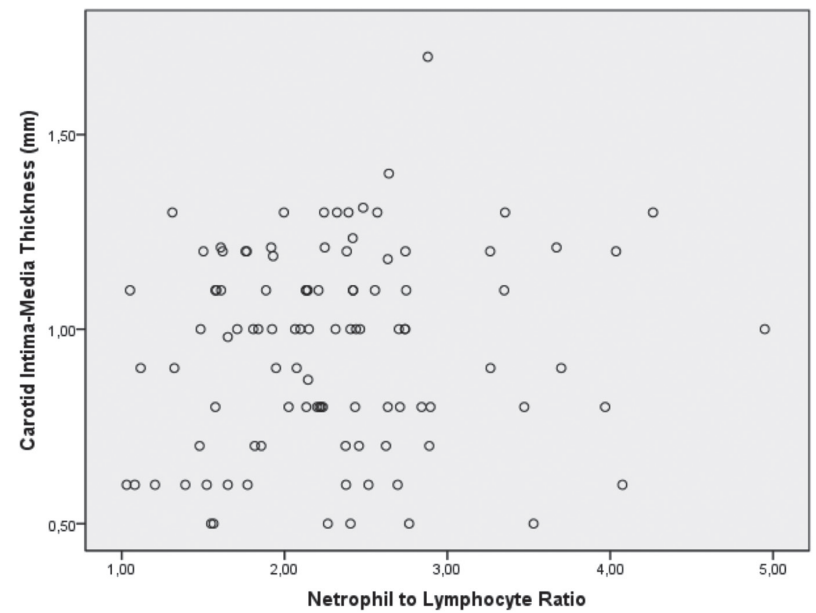

Figure 2. A. Correlation between neutrophil-lymphocyte ratio and carotid intima-media among psoriatic patients

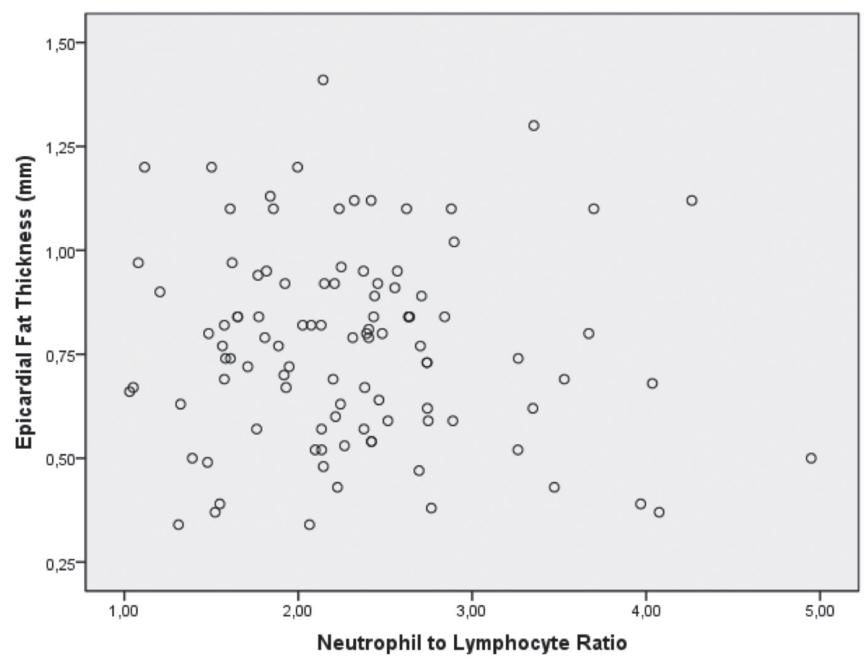

Figure 2. B. Correlation between neutrophil-lymphocyte ratio and epicardial fat thickness among psoriatic patients

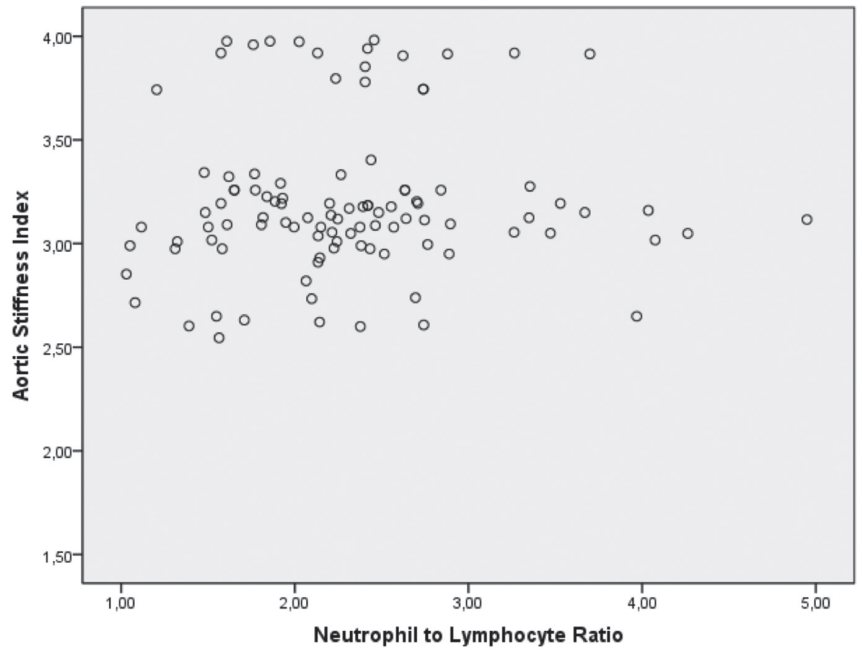

Figure 2. C. Correlation between neutrophil-lymphocyte ratio and aortic stiffness index among psoriatic patients 
estimation of vascular disease risk, a change in CIMT of only $0.1 \mathrm{~mm}$ being associated with a 13\%-18\% increase in stroke risk and a $10 \%$ $15 \%$ increase in myocardial infarction risk ${ }^{12}$. Increased CIMT has also been shown in patients with psoriasis compared with the controls, 3, 13,26. Similar to previous reports, CIMT was higher in patients with psoriasis than in healthy control subjects in this study.

EFT has recently been identified as an endocrine tissue that produces hormones, cytokines, and pro-inflammatory and pro-atherosclerotic molecules including interleukin (IL)- 6 , TNF- $\alpha$, leptin, free fatty acids, and monocyte chemoattractant protein-1 ${ }^{15,27}$. EFT accounts for approximately $1 \%$ of total body mass in a healthy adult, but this tissue may also play a key role in the pathogenesis of atherosclerosis ${ }^{14,27}$. EFT has been associated with subclinical atherosclerosis and overall cardiovascular risk, in addition to insulin resistance, DM, and metabolic syndrome $(\mathrm{MS})^{16,17,20}$. Bulbul Sen et al. ${ }^{9}$ reported an association between psoriasis and subclinical atherosclerosis markers, including CIMT and EFT. In this study, CIMT and EFT were significantly elevated among psoriasis patients relative to healthy control subjects.

Aortic elasticity was calculated by means of ASI and AD. These parameters are inversely correlated and reflect aging and atherosclerosis ${ }^{28}$. Cardiovascular risk factors accelerate the atherosclerotic process, reducing aortic elasticity by increasing ASI and reducing AD. Impaired aortic elasticity has been correlated with the extent and severity of $C A D^{29}$. Most previous studies have employed the carotid-femoral pulse wave velocity (PWV) technique to calculate vascular stiffness. The aorta provides more accurate reflection of central hemodynamics better than the femoral artery, since the latter is a highly muscular vesse ${ }^{30,31}$. Atherosclerosis has a less powerful impact on muscular vessels compared with elastic great vessels, including the aorta. The PWV method is limited by the groin exposure (this being particularly difficult in obese patients) and poor estimation of distance between two recording points (resulting in inaccurate estimates in obese patients) ${ }^{31}$. $A S I$ and $A D$ reflect the elastic properties of the aorta. The deterioration of aortic elasticity is indicated by an increase in ASI and a decrease in AD. Changes in arterial stiffness may precede early pathological intimal changes ${ }^{4,23}$. Prior reports have demonstrated a link between psoriasis and arterial stiffness and atherosclerosis ${ }^{4,23,32}$. The results of this study showed greater arterial stiffness in psoriatic patients than in healthy controls.

The pathological mechanisms linking CAD and psoriasis are the focus of intense clinical and experimental research. Several cardiovascular risk factors are prevalent among psoriasis patients, including DM, $H T$, hyperlipidemia, and MS, resulting in an increased CAD incidence among psoriasis patients ${ }^{33}$. Psoriasis is a chronic, inflammatory skin disease. Prolonged exposure to inflammatory mediators such as TNF- $\alpha$ and IL-6 may therefore exacerbate the risk of CAD. Previous studies have reported elevation in inflammatory markers such as CRP in psoriatic patients compared with healthy controls ${ }^{4,34}$. High-sensitivity CRP is an independent CAD risk factor ${ }^{23,32}$. Inflammatory biomarkers such as CRP, erythrocyte sedimentation rate, TNF- $\alpha$, and IL- 6 have all been associated with cardiovascular outcomes. NLR is calculated from the white blood cell count and has been confirmed as a biomarker of the systemic inflammatory response. Previous studies have demonstrated that a high NLR value can predict poor cardiovascular outcomes ${ }^{35-37}$. However, relatively few studies have described NLR as a predictor of subclinical atherosclerosis in psoriatic patients ${ }^{4,5}$. In this study, NLR was significantly elevated among psoriatic patients relative to healthy controls.

In this study, we determined a cut-off value of 1.60 for NLR for differentiating psoriatic patients from the controls with $83 \%$ sensitivity and $78 \%$ specificity. Meanwhile, Yurtdaş et al. ${ }^{11}$ reported a cut-off value of 2.32 with maximum sensitivity (70\%) and specificity (65\%) for the lower value of AVP, indicating subclinical atherosclerosis among psoriatic subjects. Our result was consistent with that study since Yurtdaş et al. ${ }^{11}$ determined a cut-off value for psoriatic patients with subclinical atherosclerosis who were expected to have higher NLR. Atherosclerosis itself also increases NLR ${ }^{3}$. However, further largescale randomized studies are needed to determine definitive cut-off values for differentiating psoriatic patients from healthy controls or for distinguishing psoriatic patients with subclinical atherosclerosis from those without subclinical atherosclerosis.

Topical steroids are used for treating psoriasis. Prolonged application of high-potency topical steroids and application over a wide surface may increase neutrophil numbers ${ }^{38,39}$. We used corticosteroid-containing ointments in the form of finger-tip units (FTUs) in 93\% of the cases of psoriasis in this study. One FTU represents the amount of ointment that can be spread using the tip of a tube from the tip of the index finger to the distal crease, or approximately $0.5 \mathrm{~g}$. The recommended amount for the entire face is 1 unit, hand 1 unit, foot 1 unit, arm 3 units, leg 6 units, and the trunk 14 units. If systemic absorption is to be avoided during the application of corticosteroid-containing ointments, powerful corticosteroid preparate use must not exceed 45-60 g a week or that of less powerful agents should not exceed $100 \mathrm{~g}$ a week $\mathrm{w}^{39,40}$ Our patients used levels that were too low (less than $45 \mathrm{~g}$ weekly) to affect blood parameters or used moderately potent steroids at intervals and applied these to a limited number of lesions. In addition, we evaluated serum CRP in terms of disease severity in psoriatic patients. CRP values of patients with PASI $<10$ were significantly lower than those with PASI $\geq 10$ (3.0 \pm 2.5 vs $7.1 \pm 2.8 \mathrm{mg} / \mathrm{dL} ; p<0.001)$. Steroids reduce inflammation and CRP. These findings thus confirmed that NLR values reflect psoriasis severity independent of any potential steroid effect on blood parameters.

All these findings implied an increased atherosclerosis burden among psoriatic patients. However, proving the presence of subclinical atherosclerosis via ASI, CIMT, EFT, and/or NLR is not sufficient for definite diagnosis. The measurement of these parameters may therefore be a useful addition to classic risk scoring to increase the detection of psoriatic subjects with a high cardiovascular burden. Patients with high cardiovascular risks may therefore benefit from antiaggregant therapy and lipid-lowering drugs and/or agents, which have been shown to be effective in reducing cardiovascular risk to lower BP.

\section{Study Limitations}

There are several limitations to this study; the first being the small sample size. Prospective follow-up studies are now needed to assess cardiovascular risk in psoriatic patients. Second, we did not assess the prognostic value of the arterial stiffness parameters. Magnetic resonance imaging (MRI) is the most accurate method to measure EFT. The absence of MRI data, therefore, represents another limitation of this study. Computed tomography (CT) and MRI are commonly used to evaluate EFT, although these methods cannot be applied to all patients in all situations. EFT measurement by echocardiography suffers from 
certain limitations relative to $\mathrm{MRI}$ and $\mathrm{CT}$, although it is objective, safe, inexpensive, and widely available. Finally, no angiographic investigation was performed for coronary atherosclerosis. Assessment of aortic elasticity can be problematic in patients with poor echo windows.

\section{Conclusion}

CIMT, EFT, and ASI were significantly higher in psoriatic patients in this study than in the healthy controls. Investigation of arterial stiffness parameters using echocardiographic techniques is a simple and accessible method of evaluating vascular function in psoriasis patients with normal cardiac functions. The evaluation of inflammatory biomarkers such as NLR may also be of assistance in elucidating the pathophysiology of vascular dysfunction in psoriasis patients. Arterial stiffness parameters and inflammatory biomarkers may be useful to the clinician to evaluate cardiovascular risks in psoriatic patients.

\section{Ethics}

Ethics Committee Approval: The Yozgat Bozok University Faculty of Medicine Local Ethics Committee reviewed and granted approval for all clinical protocols (approval number: 05.05.2014/67).

Informed Consent: Signed informed consent documents were provided by all study participants.

Peer-review: Externally peer-reviewed.

\section{Authorship Contributions}

Surgical and Medical Practices: E.Ç., H.E., M.F.E., Y.A., Concept: E.Ç., Design: E.Ç., H.E., M.F.E., Data Collection or Processing: E.Ç., H.E., Y.A., Analysis or Interpretation: H.E., M.F.E., Literature Search: E.Ç., H.E., M.F.E., Y.A., Writing: E.Ç., H.E., A.R.E.

Conflict of Interest: No conflict of interest was declared by the authors.

Financial Disclosure: The authors declared that this study received no financial support.

\section{References}

1. Griffiths $C E$, Barker JN: Pathogenesis and clinical features of psoriasis. Lancet 2007;370:263-71.

2. Siegel $D$, Devaraj S, Mitra A, Raychaudhuri SP, Raychaudhuri SK, Jialal I: Inşammation, atherosclerosis, and psoriasis. Clin Rev Allergy Immunol 2013:44:194-204.

3. Arruda-Olson AM, Reeder GS, Bell MR, Weston SA, Roger VL: Neutrophilia predicts death and heart failure after myocardial infarction: a communitybased study. Circ Cardiovasc Qual Outcomes 2009;2:656-62.

4. Rudiger $A$, Burckhardt OA, Harpes $P$, Müller SA, Follath F: The relative lymphocyte count on hospital admission is a risk factor for long-term mortality in patients with acute heart failure. Am J Emerg Med 2006;24:4514

5. Azab B, Jaglall N, Atallah JP, et al: Neutrophil-lymphocyte ratio as a predictor of adverse outcomes of acute pancreatitis. Pancreatology 2011;11:445-52.

6. Torun S, Tunc BD, Suvak B, et al: Assessment of neutrophil-lymphocyte ratio in ulcerative colitis: a promising marker in predicting disease severity. Clin Res Hepatol Gastroenterol 2012;36:491-7.

7. Azab B, Zaher M, Weiserbs KF, et al: Usefulness of neutrophil to lymphocyte ratio in predicting short- and long-term mortality after non-ST-elevation myocardial infarction. Am J Cardiol 2010;106:470-6.

8. Park JJ, Jang $\mathrm{HJ}$, Oh IY, et al: Prognostic value of neutrophil to lymphocyte ratio in patients presenting with ST-elevation myocardial infarction undergoing primary percutaneous coronary intervention. Am J Cardiol 2013;111:63642.
9. Bulbul Sen B, Atci N, Rifaioglu EN, et al: Increased epicardial fat tissue is a marker of subclinical atherosclerosis in patients with psoriasis. $\mathrm{Br} J$ Dermatol 2013;169:1081-6.

10. Sunbul $M$, Seckin $D$, Durmus $E$, et al: Assessment of arterial stiffness and cardiovascular hemodynamics by oscillometric method in psoriasis patients with normal cardiac functions. Heart Vessels 2015;30:347-54.

11. Yurtdaş M, Yaylali YT, Kaya Y, Ozdemir M, Ozkan I, Aladağ N: Neutrophilto-lymphocyte ratio may predict subclinical atherosclerosis in patients with psoriasis. Echocardiography 2014;31:1095-104.

12. Lorenz MW, Markus HS, Bots ML, Rosvall M, Sitzer M: Prediction of clinical cardiovascular events with carotid intima-media thickness: A systematic review and meta-analysis. Circulation 2007;115:459-67.

13. Balta S, Balta I, Mikhailidis DP, et al: Bilirubin levels and their association with carotid intima media thickness and high-sensitivity C-reactive protein in patients with psoriasis vulgaris. Am J Clin Dermatol 2014;15:137-42.

14. Balci A, Celik M, Balci DD, et al: Patients with psoriasis have an increased amount of epicardial fat tissue. Clin Exp Dermatol 2014;39:123-8.

15. lacobellis $G$, Malavazos AE, Corsi MM: Epicardial fat: from the biomolecular aspects to the clinical practice. Int J Biochem Cell Biol 2011;43:1651-4.

16. Nabati M, Saffar N, Yazdani J, Parsaee MS: Relationship between epicardial fat measured by echocardiography and coronary atherosclerosis: a singleblind historical cohort study. Echocardiography 2013;30:505-11.

17. Bachar GN, Dicker D, Kornowski R, Atar E: Epicardial adipose tissue as a predictor of coronary artery disease in asymptomatic subjects. Am J Cardiol 2012:110:534-8.

18. Erdogan D, Caliskan M, Yildirim I, et al: Effects of normal blood pressure, prehypertension and hypertension on left ventricular diastolic function and aortic elastic properties. Blood Press 2007;16:114-21.

19. Lang RM, Bierig M, Devereux RB, et al: Chamber Quantification Writing Group; American Society of Echocardiography's Guidelines and Standards Committee; European Association of Echocardiography. Recommendations for chamber quantification: A report from the American Society of Echocardiography's Guidelines and Standards Committee and the Chamber Quantification Writing Group, developed in conjunction with the European Association of Echocardiography, a branch of the European Society of Cardiology. J Am Soc Echocardiogr 2005;18:1440-63.

20. Iacobellis $\mathrm{G}$, Willens $\mathrm{HJ}$ : Echocardiographic epicardial fat: a review of research and clinical applications. J Am Soc Echocardiogr 2009;22:1311-9.

21. Katakami N, Kaneto H, Shimomura I: Carotid ultrasonography: A potent tool for better clinical practice in diagnosis of atherosclerosis in diabetic patients. J Diabetes Investig 2014;5:3-13.

22. Ramsay $B$, Lawrence CM: Measurement of involved surface area in patients with psoriasis. Br J Dermatol 1991;124:565-70.

23. Balta I, Balta S, Demirkol S, et al: Aortic arterial stiffness is a moderate predictor of cardiovascular disease in patients with psoriasis vulgaris. Angiology 2014;65:74-8.

24. Mehta NN, Yu Y, Saboury B, et al: Systemic and vascular inflammation in patients with moderate to severe psoriasis as measured by [18F]fluorodeoxyglucose positron emission tomography-computed tomography (FDG-PET/CT): a pilot study. Arch Dermatol 2011;147:1031-9.

25. Ahlehoff O, Gislason GH, Charlot M, et al: Psoriasis is associated with clinically significant cardiovascular risk: a Danish nationwide cohort study. J Intern Med 2011;270:147-57.

26. El-Mongy S, Fathy $\mathrm{H}$, Abdelaziz $\mathrm{A}$, et al: Subclinical atherosclerosis in patients with chronic psoriasis: a potential association. J Eur Acad Dermatol Venereol 2010;24:661-6

27. Torres T, Bettencourt N, Mendonça $D$, et al: Epicardial adipose tissue and coronary artery calcification in psoriasis patients. J Eur Acad Dermatol Venereol 2015;29:270-7.

28. Sethi S, Rivera O, Oliveros R, Chilton R: Aortic stiffness: pathophysiology, clinical implications, and approach to treatment. Integr Blood Press Contro 2014;7:29-34.

29. Roos CJ, Djaberi R, Schuijf JD, et al: Relationship between vascular stiffness and stress myocardial perfusion imaging in asymptomatic patients with diabetes. Eur J Nucl Med Mol Imaging 2011;38:2050-7.

30. Safar ME, Levy Bl: Studies on arterial stiffness and wave reflections in hypertension. Am J Hypertens 2015;28:1-6. 
31. Cavalcante JL, Lima JA, Redheuil A, Al-Mallah MH: Aortic stiffness: current understanding and future directions. J Am Coll Cardiol 2011;57:1511-22.

32. Yiu $\mathrm{KH}$, Yeung $\mathrm{CK}$, Chan $\mathrm{HT}$, et al: Increased arterial stiffness in patients with psoriasis is associated with active systemic inflammation. $\mathrm{Br} J$ Dermatol 2011;164:514-20.

33. Langan SM, Seminara NM, Shin DB, et al: Prevalence of metabolic syndrome in patients with psoriasis: a population-based study in the United Kingdom. J Invest Dermatol 2012;132:556-62.

34. Montaudié $H$, Albert-Sabonnadière $C$, Acquacalda $E$, et al: Impact of systemic treatment of psoriasis on inflammatory parameters and markers of comorbidities and cardiovascular risk: results of a prospective longitudinal observational study. J Eur Acad Dermatol Venereol 2014;28:1186-91.

35. Tamhane UU, Aneja S, Montgomery D, Rogers EK, Eagle KA, Gurm HS: Association between admission neutrophil to lymphocyte ratio and outcomes in patients with acute coronary syndrome. Am J Cardiol 2008;102:653-7.
36. Uthamalingam S, Patvardhan EA, Subramanian S, et al: Utility of the neutrophil to lymphocyte ratio in predicting long-term outcomes in acute decompensated heart failure. Am J Cardiol 2011;107:433-8.

37. Sunbul M, Gerin F, Durmus E, et al: Neutrophil to lymphocyte and platelet to lymphocyte ratio in patients with dipper versus non-dipper hypertension. Clin Exp Hypertens 2014;36:217-21.

38. van de Kerkhof PCM, Schalkwjk J: Psoriasis. Dermatology. Ed. Bologna JL, Jorizzo JL, Rapini RP. Edinburgh Scotland, Mosby 2008:115-35.

39. Valencia I, Kerdel F. Topical corticosteroids. Fitzpatrick's Dermatology in General Medicine. Ed. Wolff K, Goldsmith LA, Katz SI, Gilchrest BA, Paller AS, Leffell DJ. New York, Mc Graw Hill 2008:2102-6.

40. Long CC, Finlay AY: The finger-tip unit-a new practical measure. Clin Exp Dermatol 1991;16:444-7. 